\title{
PERBANDINGAN KEMAMPUAN BERPIKIR DIVERGEN ANTARA SISWA LAKI-LAKI DAN PEREMPUAN PADA MATA PELAJARAN BIOLOGI DI KELAS XI SMA NEGERI 9 MAKASSAR
}

\author{
Nurul Alia Ulfa ${ }^{1}$, Nurhayati $B^{2}$, Muhammad Junda ${ }^{3}$ \\ ${ }^{1}$ Universitas Pendidikan Muhammadiyah Sorong \\ ${ }^{2}$ Universitas Negeri Makassar \\ ${ }^{3}$ Universitas Negeri Makassar \\ nurulalia.ulfha@gmail.com
}

\begin{abstract}
Abstrak
Tujuan penelitian ini adalah untuk mendeskripsikan kemampuan berpikir divergen siswa laki-laki dan perempuan pada mata pelajaran Biologi di SMA Negeri 9 Makassar, dan untuk mengetahui adakah perbedaan signifikan kemampuan berpikir divergen antara siswa laki-laki dan perempuan pada mata pelajaran Biologi di SMA Negeri 9 Makassar. Metode yang digunakan dalam penelitian ini yaitu penelitian ex post facto.Populasi berjumlah 248 orang. Pengambilan sampel menggunakan tekhnik Purposive Sampling berjumlah 67 orang. Penelitian ini dilaksanakan pada bulan Juli sampai September 2018 tahun pelajaran 2018/2019. Tempat penelitian di SMA Negeri 9 Makassar yang terletak di Jalan Karunrung Raya No 37, Karunrung, Rappocini, Kota Makassar, Sulawesi Selatan. Instrumen yang digunakan dalam penelitian ini yaitu menggunakan tes kreatifitas verbal. Hasilnya menunjukkan bahwa kemampuan berpikir divergen siswa laki-laki dan perempuan di kelas XI SMA Negeri 9 Makassar berada pada kategori baik, terdapat perbedaan signifikan kemampuan berpikir divergen antara siswa laki-laki dan perempuan dengan nilai sig. (2-tailed) 0,024 pada taraf sig. $\alpha \quad 0,05$. Kemampuan berpikir divergen siswa perempuan lebih tinggi daripada siswa laki-laki.
\end{abstract}

Kata kunci: Kemampuan berpikir divergen, laki-Laki, perempuan

\begin{abstract}
The purpose of this study is to describe the divergent thinking skills of male and female students in biology at SMA Negeri 9 Makassar, and to understand whether there are significant differences between divergent thinking skills for male and female students in biology at SMA Negeri 9 Makassar. The method used in this study was ex post fact research. The study population was 248 people. Sampling using Purposive Sampling technique collected 67 people. This research was conducted in July to September 2018 2018/2019 school year. The research site is Makassar 9 Public High School which is located at Jalan Karunrung Raya No 37, Karunrung, Rappocini, Makassar City, South Sulawesi. The instrument used in this study was to use verbal creativity tests. The results show that the divergent thinking ability of male and female students in class XI of SMA Negeri 9 Makassar is in the good category, there is a significant difference in the divergent thinking ability of male and female students with sig. (2-tailed) 0.024 at sig. $\alpha$ 0.05. Divergent thinking abilities of female students are higher than male students.
\end{abstract}

Keywords: Divergent thinking ability, male, female

\section{PENDAHULUAN}

Peningkatkan mutu pendidikan yang sejalan dengan perkembangan teknologi, pemerintah menaruh perhatian terhadap mutu proses pembelajaran. Mengingat percepatan perkembangan ilmu pengetahuan dan tekhnologi yang terjadi, tidak memungkinkan bagi guru bertindak sebagai satusatunya orang yang menyalurkan semua fakta dengan menggunakan metode ceramah yang dilakukan di sekolah. Untuk mengatasi hal ini perlu pengembangan keterampilan memperoleh dan memproses semua fakta, konsep, dan prinsip pada diri siswa (1).

Terdapat perbedaan karakteristik peserta didik didalam kelas. Perbedaan gender merupakan satu dari berbagai macam perbedaan yang ada. Siswa lakilaki dan perempuan memiliki perbedaan dalam beberapa hal. Beberapa penelitian telah mengungkapkan beberapa perbedaan siswa ditinjau dari perbedaan gender (2).
Perbedaan jenis kelamin membuat setiap individu berbeda dengan individu lainnya, seperti lakilaki berbeda dibanding perempuan dalam banyak aspek termasuk dalam hal kecerdasan, minat, ingatan, emosi dan kemauan. Secara umum laki-laki bersifat lebih aktif, memberi, melindungi, meniru pribadi pujaannya dan lebih berminat kepada hal-hal yang intelektual. Sedangkan, perempuan cenderung bersifat pasif dan menerima, ingin dilindungi, mengagumi pribadi pujaannya, lebih berminat kepada hal-hal yang bersifat emosional serta cenderung berusaha menyenangkan orang lain (3).

Pengembangan kreativitas dalam keterampilan proses sains, artinya dapat mengembangkan pula kemampuan berpikir divergen peserta didik. Dalam konteks pembelajaran, salah satu tujuan pembelajaran adalah membentuk anak menjadi kreatif (4). Salah satu ciri khas kreativitas adalah berpikir divergen. Kemampuan berpikir divergen 
sangat diperlukan oleh seseorang untuk memecahkan permasalahan secara kritis dan kreatif (5).

Berpikir pola divergen merupakan pemikiran yang menghasilkan bermacam-macam kemungkinan jawaban/gagasan dalam memecahkan suatu masalah, kemampuan berpikir divergen dapat dinyatakan sebagai keterampilan siswa dalam pengembangan gagasan kreatif oleh adanya stimulus dengan ciri tipikal yang terjadi secara spontan dan bebas dari caracara tertentu. kemampuan berpikir divergen sangat penting dikembangkan pada diri siswa melalui pembelajaran (6).

Pengembangan kreativitas peserta didik harus dilakukan dalam setiap pelaksanaan pembelajaran di sekolah, termasuk pada pelaksanaan pembelajaran Ilmu Pengetahuan Alam (IPA)/Sains. Sains merupakan ilmu pengetahuan yang mempelajari berbagai peristiwa di alam. Sains mencakup tiga komponen, yaitu proses ilmiah, sikap ilmiah, dan produk ilmiah (Carin \& Sund, 1970). Biologi merupakan salah satu cabang dari IPA. Pengembangan kreativitas peserta didik juga harus dilakukan pada pembelajaran biologi di sekolah.

Ada enam faktor yang dapat menyebabkan adanya variasi dalam kreativitas (termasuk di dalamnya adalah divergen). Keenam faktor tersebut adalah gender, status sosio ekonomi, urutan kelahiran, ukuran keluarga, lingkungan kota versus lingkungan pedesaan, dan intelegensi. Salah satu faktor yang menarik untuk diteliti adalah faktor gender.

Berdasarkan hasil observasi di SMA Negeri 9 Makassar, bahwa dalam proses pembelajaran guru masih menekankan cara berpikir konvergen, guru masih berfokus ke satu titik jawaban. Prinsip pembelajaran dalam Kurikulum 2013 selain mengembangkan kemampuan berpikir konvergen juga mengembangkan kemampuan berpikir divergen yang ditunjukkan pada salinan lampiran Permendikbud No. 65 tahun 2013 tentang Standar Proses Pendidikan Dasar dan Menengah pada bagian pendahuluan bahwa dari pembelajaran yang menekankan jawaban tunggal menuju pembelajaran dengan jawaban yang kebenarannya multi dimensi.

Berdasarkan permasalahan yang telah diuraikan diatas maka tujuan penelitian ini adalah untuk mendeskripsikan kemampuan berpikir divergen siswa laki-laki dan perempuan pada mata pelajaran Biologi di SMA Negeri 9 Makassar, dan untuk mengetahui adakah perbedaan signifikan kemampuan berpikir divergen antara siswa laki-laki dan perempuan pada mata pelajaran Biologi di SMA Negeri 9 Makassar.

\section{METODE PENELITIAN}

Metode yang digunakan dalam penelitian ini yaitu penelitian ex post facto. Populasi dalam penelitian ini adalah semua siswa kelas XI MIA SMA Negeri 9 Makassar yang terdiri dari 7 rombongan belajar 7 yang berjumlah 248 orang. Pengambilan sampel dalam penelitian menggunakan tekhnik
Purposive Sampling. Sampel dalam penelitian ini yaitu kelas XI MIA 1 dan XI MIA 2 yang berjumlah 67 orang. Penelitian ini dilaksanakan pada bulan Juli sampai September 2018 tahun pelajaran 2018/2019. Tempat penelitian di SMA Negeri 9 Makassar yang terletak di Jalan Karunrung Raya No 37, Karunrung, Rappocini, Kota Makassar, Sulawesi Selatan. Instrumen yang digunakan dalam penelitian ini yaitu menggunakan tes kreatifitas verbal.

Penelitian ini dilakukan dalam tiga tahap, yaitu tahap pertama adalah tahap persiapan, tahap kedua adalah tahap pelaksanaan penelitian dan tahap ketiga adalah tahap akhir. Teknik pengumpulan data pada penelitian ini dikumpulkan melalui tes yaitu tes kemampuan berpikir divergen yang berupa tes kreatifitas verbal verbal. Teknik analisis data menggunakan analisis statistik deskriptif dan statisk inferensial.

Pengolahan data hasil kemampuan berpikir divergen siswa dilakukan dengan langkah-langkah sebagai berikut: Instrumen yang digunakan dalam mengumpulkan data kemampuan berpikir divergen adalah tes kreativitas verbal. Untuk memperoleh data yang valid mengenai kemampuan berpikir divergen siswa SMA Negeri 9 Makassar, maka kemampuan berpikir divergen dihitung berdasarkan hasil tes yang diberikan kemudian di olah berdasarkan tabel skor yang telah ditentukan. Kriteria yang digunakan untuk menentukan kategori kemampuan berpikir divergen siswa diadaptasi dari kategori kemampuan berpikir kreatif disajikan pada Tabel 1.

Tabel 1 Pengkategorian Kemampuan Berpikir Divergen Siswa

\begin{tabular}{lc}
\hline Interval Skor & Kategori \\
\hline $81-100$ & Sangat Baik \\
$61-80$ & Baik \\
$41-60$ & Cukup \\
$21-40$ & Kurang \\
$0-20$ & Sangat Kurang \\
\hline
\end{tabular}

Analisis inferensial yang digunakan dalam penelitian ini yaitu uji normalitas, uji homogenitas, dan uji hipotesis komparasional. Pengujian normal tidaknya data pada penelitian ini menggunakan program SPSS versi 22 for windows melalui uji Kolmogorov Smirnov. Uji ini dilakukan sebagai prasyarat dalam analisis Independent Samples T-Test. Asumsi homegenitas dapat diketahui dengan membandingkan nilai probabilitas Sig. yang telah ditentukan $(\alpha=0,05)$. Asumsinya adalah jika probabilitas Sig. lebih besar dari taraf probabilitas $\alpha=$ $0,05$ atau ( $\operatorname{sig}>\alpha=0,05)$, artinya data berasal dari populasi yang homogen begitupun sebaliknya.

Pengujian hipotesis digunakan uji Independent Sampel t-Test atau Uji-t. tujuan Uji-t dua variable bebas adalah untuk membandingkan apakah kedua variable tersebut sama atau berbeda. Selain itu, gunanya untuk menguji kemampuan generalisasi (signifikansi hasil penelitian yang berupa 
perbandingan dua rata-rata sampel). Dasar pengambilan keputusan: Jika nilai signifikansi atau sig. (2-tailed) $>0,05$, maka $\mathrm{H}_{0}$ diterima dan $\mathrm{H}_{\mathrm{a}}$ ditolak. Jika nilai signifikansi atau sig. (2-tailed) $<0,05$, maka $\mathrm{H}_{0}$ ditolak dan $\mathrm{H}_{\mathrm{a}}$ diterima.

\section{H PEMBAHASAN}

Proses Pengumpulan data variabel kemampuan berpikir divergen siswa laki-laki dan perempuan dilakukan dengan cara memberikan tes kemampuan berpikir divergen, kemudian diolah dengan statistik deskriptif menggunakan SPSS versi 22 for windows. Data kemampuan berpikir divergen siswa laki-laki dan perempuan yang diperoleh dapat dilihat pada Tabel 2.

Tabel 2. Hasil Analisis Statistik Deskriptif Kemampuan Berpikir Divergen Siswa Laki-Laki dan Perempuan di SMA Negeri 9 Makassar

\begin{tabular}{lcc}
\hline \multicolumn{1}{c}{ Statistik Deskriptif } & \multicolumn{2}{c}{ Nilai Statistik } \\
\cline { 2 - 3 } & Laki-Laki & Perempuan \\
\hline N (ukuran sampel) & 32 & 35 \\
Nilai Maksimum & 85 & 95 \\
Nilai Minimum & 50 & 50 \\
Rata-Rata & 67,50 & 73,43 \\
Median & 67,50 & 75 \\
Varians & 87,09 & 130,55 \\
Standar Deviasi & 9,33 & 11,43 \\
\hline
\end{tabular}

Berdasarkan Tabel 2 menunjukkan hasil analisis statistik deskriptif kemampuan berpikir divergen siswa laki-laki dengan jumlah sampel sebanyak 32 orang siswa, diketahui bahwa nilai maksimum yang diperoleh adalah 85 , nilai minimum adalah 50, dengan nilai rata-rata sebesar 67,50. Median yaitu 67,50, varians sebesar 87,09 dan standar deviasi sebesar 9,33.

Siswa perempuan dengan jumlah sampel sebanyak 35 orang siswa, diketahui bahwa nilai maksimum yang diperoleh adalah 95, nilai minimum adalah 50, dengan nilai rata-rata sebesar 73,43. Median atau nilai tengah yaitu 75, varians sebesar 130,55 dan standar deviasi sebesar 11,43. Data hasil perhitungan tes kemampuan berpikir divergen siswa laki-laki dan perempuan kemudian dikelompokkan dalam lima kategori berdasarkan skor yang didapatkan. Data tersebut dapat dilihat pada Tabel 3.

Tabel 3 Distribusi Frekuensi dan Persentase Kemampuan Berpikir Divergen Siswa LakiLaki dan Perempuan di Kelas XI SMA Negeri 9 Makassar

\begin{tabular}{cccccc}
\hline $\begin{array}{c}\text { Interval } \\
\text { Skor }\end{array}$ & \multicolumn{2}{c}{ Jumlah } & \multicolumn{2}{c}{$\begin{array}{c}\text { Persentase } \\
(\%)\end{array}$} & $\begin{array}{c}\text { Klasifika } \\
\text { si }\end{array}$ \\
\cline { 2 - 5 } & Lk & Pr & Lk & Pr & \\
\hline $81-100$ & 2 & 8 & 6,25 & 22,8 & $\begin{array}{c}\text { Sangat } \\
\text { Baik }\end{array}$ \\
& & & & 6 & Baik \\
$61-80$ & 21 & 20 & 65,63 & 57,1 & Baik \\
& & & & 4 & \\
$41-60$ & 9 & 7 & 28,13 & 20 & Cukup \\
$21-40$ & 0 & 0 & 0 & 0 & Kurang
\end{tabular}

\begin{tabular}{cccccc}
$0-20$ & 0 & 0 & 0 & 0 & $\begin{array}{c}\text { Sangat } \\
\text { Kurang }\end{array}$ \\
\hline Jumlah & 32 & 35 & & & \\
\hline
\end{tabular}

kemampuan berpikir divergen

Keterangan:

Lk : Laki-laki

Pr : Perempuan

Berdasarkan Tabel 3 menunjukkan dari 32 orang jumlah sampel siswa laki-laki diketahui bahwa 2 orang berada pada kategori sangat baik dengan persentase sebesar $6,25 \%, 21$ orang berada pada kategori baik dengan persentase sebesar 65,63\%, dan 9 orang berada pada kategori cukup dengan persentase sebesar 28,13\%. Berdasarkan data tersebut mengindikasikan bahwa kemampuan berpikir divergen siswa laki-laki kelas XI SMA Negeri 9 Makassar berada pada kategori baik.

Jumlah sampel siswa perempuan sebanyak 35 orang diketahui bahwa 8 orang berada pada kategori sangat baik dengan persentase sebesar 22,86\%, 20 orang berada pada kategori baik dengan persentase sebesar $57,14 \%$, dan 7 orang berada pada kategori cukup dengan persentase sebesar $20 \%$. Berdasarkan data tersebut mengindikasikan bahwa kemampuan berpikir divergen siswa perempuan kelas XI SMA Negeri 9 Makassar berada pada kategori baik.

Data kemampuan berpikir divergen diperoleh melalui tes kemampuan berpikir divergen. Kemudian dianalisis menggunakan SPSS versi 22 for windows untuk mencari perbandingan kemampuan berpikir divergen antara siswa laki-laki dan perempuan menggunakan uji Independent Sampels t-Test. Namun sebelum melakukan uji Independent Sampesl t-Test, terlebih dahulu dilakukan uji prasyarat analisis yakni uji normalitas dan uji homogenitas.

Hasil perhitungan statistik menggunakan uji Independent Samples t-Test diperoleh nilai sig. Kemampuan berpikir divergen adalah adalah 0,024. Dasar pengambilan keputusan: Jika nilai signifikansi atau sig. (2-tailed) > 0,05, maka $\mathrm{H}_{0}$ diterima dan $\mathrm{H}_{\mathrm{a}}$ ditolak. Jika nilai signifikansi atau sig. (2-tailed) < 0,05, maka $\mathrm{H}_{0}$ ditolak dan $\mathrm{H}_{\mathrm{a}}$ diterima. Sesuai dasar pengambilan keputusan dalam uji Independent Sampel $t$-Test, jika nilai signifikansi atau sig. (2-tailed) < 0,05, maka $\mathrm{H}_{0}$ ditolak dan $\mathrm{H}_{\mathrm{a}}$ diterima $(0,024<0,05)$, maka dapat disimpulkan bahwa terdapat perbedaan signifikan kemampuan berpikir divergen antara siswa laki-laki dan perempuan pada mata pelajaran Biologi di kelas XI SMA Negeri 9 Makassar.

Hasil penelitian menunjukkan bahwa kemampuan berpikir divergen siswa perempuan lebih tinggi daripada siswa laki-laki. Hasil tersebut sesuai dengan teori oleh (7) bahwa kreativitas dipengaruhi oleh gender. Hal ini juga didukung oleh penelitian yang dilakukan oleh (8) yang menyatakan bahwa skor rata-rata kemampuan berpikir divergen siswa perempuan lebih tinggi dibandingkan dengan siswa laki-laki.(9) dalam bukunya mengatakan bahwa : (1) 
Selama periode awal sekolah sampai remaja, kemampuan verbal anak laki-laki sama dengan anak perempuan, tetapi setelah umur 12 tahun kemampuan verbal anak perempuan lebih baik daripada anak lakilaki. Penelitian lain yang dilakukan oleh Matud, Rodriguez, dan (10) menyatakan bahwa terdapat perbedaan signifikan kemampuan berpikir divergen antara laki-laki dan perempuan, dimana perempuan memiliki kemampuan berpikir divergen yang lebih tinggi.

Dari berbagai penelitian tentang kreativitas ditemukan adanya hubungan antara perbedaan jenis kelamin dan tingkat kreativitas baik dalam bentuk kuantitas maupun kualitas. Hasil analisis mereka terhadap jurnal penelitian dari tahun 1958-1998 ditemukan adanya perbedaan baik pada aspek fluency, flexibility, originality, dan elaboration. Perempuan cenderung lebih tinggi pada aspek fluency, originality, dan elaboration. Sedangkan pada aspek flexibility lakilaki cenderung lebih tinggi walau perbedaannya tidak terlalu tinggi (11).

Perbandingan dalam hal kreativitas telah dilakukan oleh (12) pada sekolah menengah di Indonesia yang menemukan bahwa kreativitas perempuan cenderung lebih tinggi dari laki-laki dengan perbandingan $58 \%$ berbanding $42 \%$. Hasil yang sama ditemukan (13) yang berdasarkan hasil penelitian pada 82 anak yang mempunyai tingkat kreativitas tinggi ternyata lebih banyak diperoleh anak perempuan dibanding laki-laki dengan perbandingan $35(53 \%)$ berbanding 31 (47\%).

Adanya perbedaan antara laki-laki dan perempuan dalam berbagai aspek psikologis, khususnya dalam kreativitas bisa dipahami dari berbagai sudut pandang. Brizendine (2006) seorang ahli neuropsikiatri dan direktur klinik khusus mengkaji fungsi otak perempuan menjelaskan bahwa memang secara struktur ada perbedaan antara otak laki-laki dan perempuan, hal ini berakibat pada perbedaan keduanya dalam cara berpikir, cara memandang sesuatu, cara berkomunikasi, dan lain sebagainya.

Seseorang dengan pemikiran divergen ketika dihadapkan pada suatu permasalahan akan memiliki keterampilan berpikir lancar atau keterampilan berpikir seperti ini dapat terlihat melalui kemampuan mencetuskan banyak ide-ide yang orisinil dan lain daripada yang lain. Beberapa ide yang dicetuskan oleh individu dengan kemampuan berpikir divergen ini dilihat dari sudut pandang yang berbeda- beda. Setelah mencetuskan beberapa ide-ide seseorang dengan kemampuan berpikir divergen ini akan mencari satu jalan keluar yang paling cocok digunakan untuk menyelesaikan permasalahan yang dihadapinya (14).

Menurut Guilford berpikir divergen adalah faktor kunci dalam kreativitas, dan ia mengaitkannya dengan empat bahan utama. Yang pertama adalah elaborasi: kemampuan untuk memikirkan detail dan melaksanakannya. Yang kedua adalah fleksibilitas: kapasitas untuk memikirkan berbagai pendekatan secara bersamaan. Ketiga adalah kefasihan: kemampuan untuk menghasilkan sejumlah besar ide dengan cepat. Terakhir adalah orisinalitas: keahlian untuk mengembangkan ide yang berbeda dari ide kebanyakan orang (15).

Ada banyak kemungkinanan faktor yang memepengaruhi kemampuan berpikir divergen, diantaranya yaitu mengidentifikasi memori, informasi, pengalaman, dan lingkungan (16). Menurut hasil penelitian yang dilakukan oleh Claxton, Pannells, \& Rhoads (17) menyatakan bahwa semua penelitian yang dipublikasikan pada kemampuan berpikir divergen dan perbedaan tingkat usia atau kelas dalam hasil tes. Kecemasan juga telah terbukti mempengaruhi kemampuan berpikir divergen.

Berpikir pola divergen merupakan pemikiran yang menghasilkan bermacam-macam kemungkinan jawaban/gagasan dalam memecahkan suatu masalah, sedangkan berpikir pola konvergen memberikan hasil berupa satu jawaban yang paling tepat terhadap suatu persoalan. kemampuan berpikir divergen dapat dinyatakan sebagai keterampilan siswa dalam pengembangan gagasan kreatif oleh adanya stimulus dengan ciri tipikal yang terjadi secara spontan dan bebas dari cara-cara tertentu (18)

\section{KESIMPULAN}

Berdasarkan hasil penelitian yang telah dilakukan maka dapat disimpulkan bahwa Kemampuan berpikir divergen siswa laki-laki dan perempuan di kelas XI SMA Negeri 9 Makassar berada pada kategori baik, terdapat perbedaan signifikan kemampuan berpikir divergen antara siswa laki-laki dan perempuan dengan nilai sig. (2-tailed) 0,024 pada taraf sig. $\alpha$ 0,05. Kemampuan berpikir divergen siswa perempuan lebih tinggi daripada siswa laki-laki.

\section{UCAPAN TERIMA KASIH}

Terimakasih kepada seluruh pihak yang telah membantu penelitian ini terutama kedua orang tua yang telah memberi motivasi dan dukungan yang tiada henti, guru bidang studi Biologi di SMA Negeri 9 Makassar, serta rekan-rekan sejawat di PPs UNM.

\section{DAFTAR PUSTAKA}

1. Hadiana., L., R., Pengaruh Pendekatan Keterampilan Proses Sains Terhadap Hasil Belajar Biologi Siswa. Tesis. UIN Syarif Hidayatullah Jakarta. 2011.

2. Elliot, S. N., Kratochwill, T. R., Cook, J. L. \& Travers, J. F. Educational Psycology: Effective Teaching, Effective Learning, Third Edition. United States of America: McGraw-Hill Companies, Inc. 2000.

3. Suryabrata, S. Psikologi Pendidikan. Yogyakarta: Bina Pustaka. 2008.

4. Hasanah, F. N., Subali, B. \& Paidi. Kemampuan Berpikir Divergen Keterampilan Proses Sains Siswa SMA Negeri Kulon Progo Berdasarkan Potensi Siswa. Jurnal Pendidikan Biologi, 5 (5), 51-58. 2016. 
5. Santrock, J. W. Psikologi Pendidikan Edisi Kedua. Jakarta: Salemba Humanika. 2014.

6. Ikhsanuddin. Kemampuan Berpikir Divergen Keterampilan Proses Sains Aspek Biologi Siswa SD Berdasarkan Kegiatan Bimbingan Belajar. Jurnal Pendidikan Biologi, 5 (1), 19-29. 2015.

7. Haqqoh, A. 2016. Stres Kerja Karyawan dan Kemampuan Berpikir Divergen. Jurnal Ilmiah Psikologi Terapan, 4(1), 16-30.

8. Mawarsari, O., Subali, B., \& Wibowo, Y. Kreativitas Keterampilan Proses Sains Aspek Kehidupan Siswa SD Berdasarkan Aspek Gender. Jurnal Pendidikan Biologi, 5(3), 44-55. 2016.

9. Casey, M. B., Ronald L., Nuttall. \& Elizabeth P. (2001). Spatial Mechanical Reasoning Skills Versus Math Self Confidence as Mediators of Gender Differences on Math Substests Using Cross National Gender-Based Items. Journal for Research in Math Education. 121-142.

10. Matud., M. P., Rodrigues. C., \& Grande, J. Gender Differences in Creative Thinking. Personality and Individual Differences 43, 11371147. 2007.

11. Cramond B., Morgan, J.M., Bandalos, D., \& Zuo, L. A Report on the 40-Year Follow-Up of the Torrance Test of Creative Thinking: Alive and Well in the New Millenium, Gifted Child Quarterly. Creativity Research Journal, 49(4), 283-291. 2005

12. Munandar, U. Pengembangan Kreativitas Anak Berbakat. Jakarta: Rineka Cipta. 2014.

13. Aziz, R. Studi tentang Kreativitas pada Siswa Sekolah Menengah Pertama di Kota Malang. Psikoislamika, 3(2), 239-254. 2010

14. Haqqoh, A. 2016. Stres Kerja Karyawan dan Kemampuan Berpikir Divergen. Jurnal Ilmiah Psikologi Terapan, 4(1), 16-30.

15. Roue, L. C. A Study of Grade Level and Gender Differences in Divergent Thinking among 8th and 11th Graders in a Mid-Western School District. A Dissertation Submitted to The Faculty of The Graduate School Of the University of Minnesota. 2011.

16. Roue, L. C. A Study of Grade Level and Gender Differences in Divergent Thinking among 8th and 11th Graders in a Mid-Western School District. A Dissertation Submitted to The Faculty of The Graduate School Of the University of Minnesota. 2011.

17. Claxton, A. F., Pannells, T. C., \& Rhoads, P. A. (2005). Developmental Trends in Creativity of School-Age Children. Creativity Research Journal, 17(4), 327-335.

18. Subali, B. Kemampuan Berpikir Pola Divergen dan Berpikir Kreatif Dalam Keterampilan Proses Sains. Yogyakarta: UNY Press. 2013. 